\title{
Formation of layering of the Lovozero peralkaline intrusion (Kola Peninsula, Russia): new data
}

\author{
J. A. Mikhailova*, Ya. A. Pakhomovsky, A. O. Kalashnikov and V. N. Yakovenchuk \\ Geological Institute of the Kola Science Centre, Russian Academy of Sciences \\ *Corresponding author e-mail: mikhailova@geoksc.apatity.ru
}

Summary The Lovozero peralkaline massif is a layered intrusion. To establish the mechanisms of the formation of layering, studies of the chemical composition of rock-forming minerals (clinopyroxenes, amphiboles, eudialyte-group minerals) were carried out. It was assumed that the layering was formed as a result of fractional crystallization of relatively small portions of the alkaline melt.

\section{Introduction and background to current research}

The Lovozero peralkaline massif intruded through the Archean granite-gneiss and Devonian volcaniclastic rocks ca. $360 \mathrm{Ma}$ ago (Kramm, Kogarko, 1994) and formed a large laccolith-type body. According to geophysical studies, alkaline rocks are traced to a depth of $7 \mathrm{~km}$, the lower limit of their distribution is not detected (Gerasimovsky et al., 1966). In the upper part, the intrusion contacts with host rocks are almost vertical. The Lovozero massif consists of two macro units: the Eudialyte complex (at the top) and the Layered complex (Fig. 1). Among the rocks of the Eudialyte and Layered complexes, there are many xenoliths of volcaniclastic rocks. There are both unchanged xenoliths, which consist of olivine basalt, basalt tuff, tuffite, sandstone, quartzite, and intensely metasomatized xenoliths. Additionally, poikilitic foid syenites form lenses and rounded bodies among rocks of the Layered and Eudialyte complexes. Almost all pegmatites and hydrothermal veins of the Lovozero massif containing various raremetal minerals are associated with these rocks.
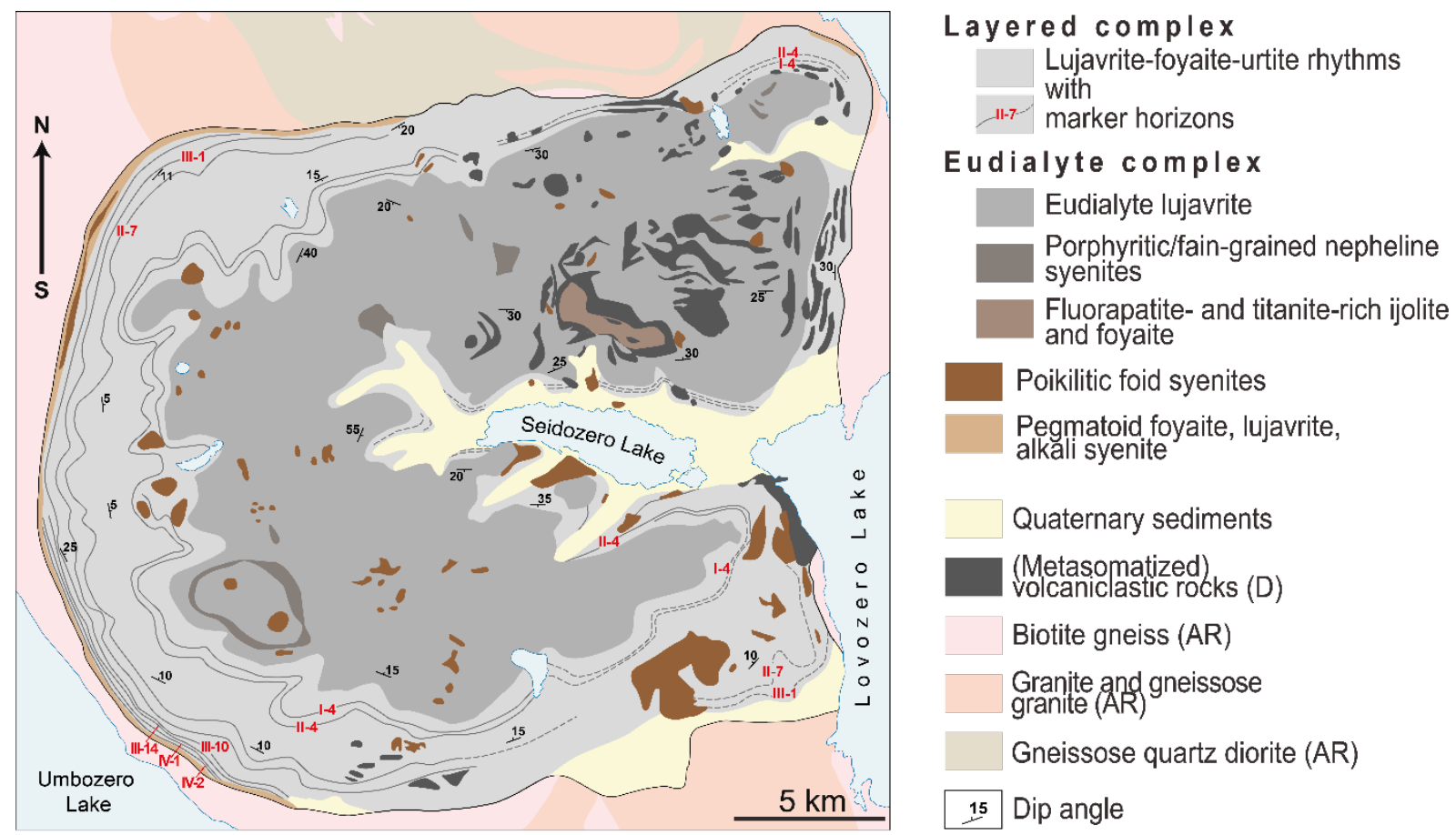

Figure 2. Geological scheme of the Lovozero massif (after Bussen, Sakharov, 1972). 
The Layered complex is the largest complex of the massif. It consists of the subhorizontal layers (or rhythms). The bottom of each rhythm is composed of urtite (Fig. 2c). Higher in the cross-section, the content of alkali feldspar increases, and urtite gradually turns into foyaite (leucocratic nepheline syenite, Fig. 2b). At the top of the rhythm, the content of mafic minerals, such as pyroxene and amphiboles, increases, and foyaite gradually passes into lujavrite (trachytoid melanocratic nepheline syenite, Fig. 2a). Contacts between rhythms are sharp. In addition, there are pegmatites at the contacts between the rhythms. Ideal rhythms (Fig. 2d) are found only in the upper part of the Layered complex. The middle part consists of lujavrite with foyaite lenses, and the lower part consists of lujavrite-foyaite rhythms with urtite lenses.

The mechanisms of the formation of the Lovozero massif layering are considered in the classical investigations of the 50-70s of the last century. Its formation was proposed to be a result of the rhythmic crystallization of a single magma chamber from top to bottom (Vlasov et al., 1959), from the bottom upwards (Gerasimovsky et al., 1966), by isolation in a single magma basin portions of silicate melts of different composition (Bussen, Sakharov, 1972).
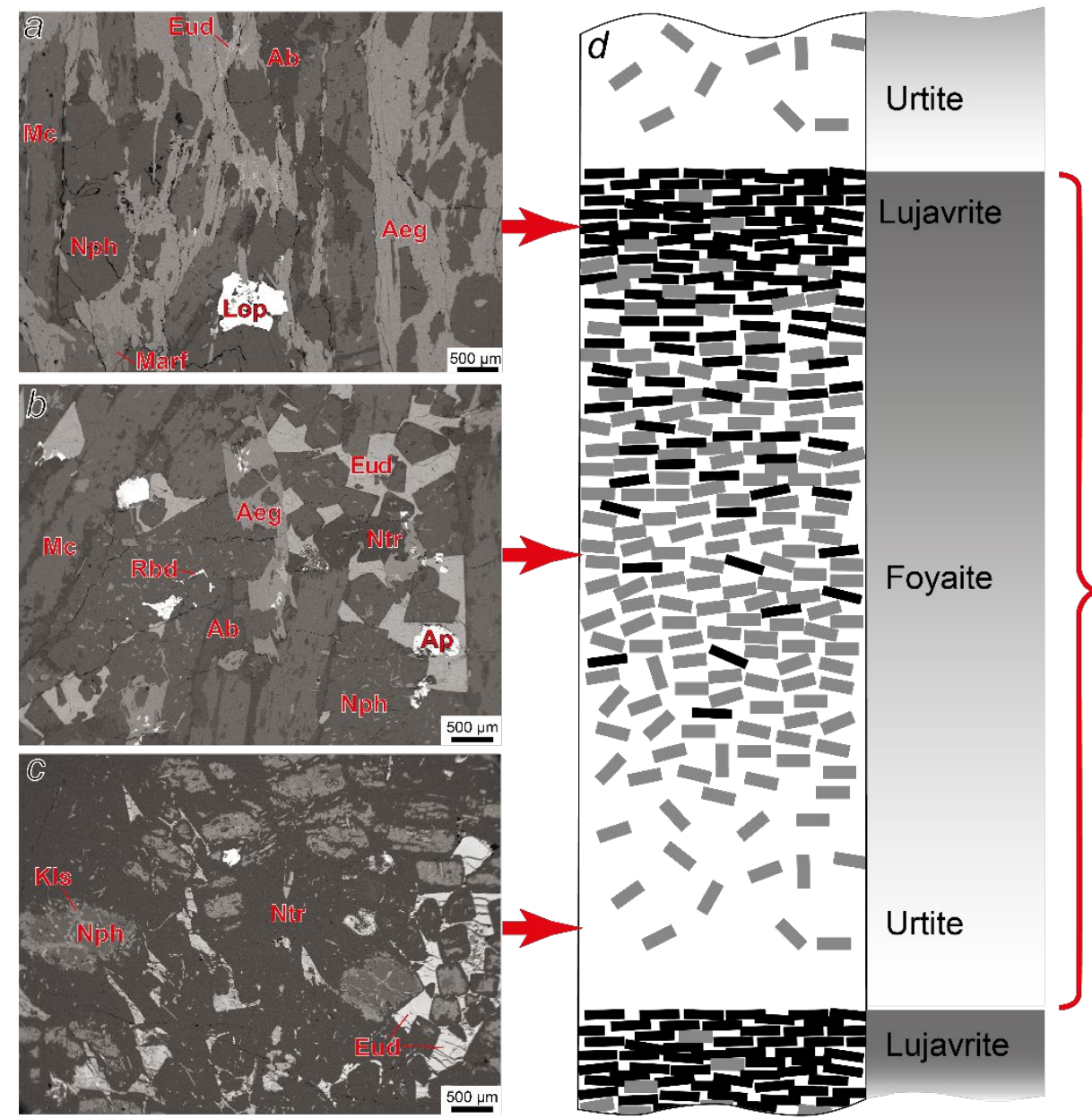

one rhythm

Figure 2. Varieties of rocks of the layered complex: (a) melanocratic nepheline syenite (lujavrite); (b) leucocratic nepheline syenite (foyaite); (c) urtite. Backscattered electron (BSE) images. Ab - albite, Ap - fluorapatite, Eud - eudialyte-group minerals, Kls - kalsilite, Lop - loparite-(Ce), Marf magnesioarfvedsonite, Mc - microcline, Rbd - rhabdophane-(Ce), Ntr - natrolite. (d) - schematic representation of an idealised cyclic unit or "rhythm" (after Arzamastsev, 1994). 
Kogarko (Kogarko et al., 2006) concluded that fractional crystallization from bottom to top of a single batch of peralkaline magma was the main process governing the formation of the Lovozero pluton layering. Féménias and colleagues (Féménias et al., 2005) concluded that the rhythm II-7 was formed as a result of intrusion into solid host rocks. In other terms, this rhythm is a sill.

\section{Research questions at hand}

Our research is aimed at establishing the mechanisms of the formation of the Lovozero massif layering. We are currently focusing on the study of changes in the chemical composition, morphology, and mineral associations of rock-forming minerals, such as pyroxenes, amphiboles, nepheline, potassium feldspar, minerals of the eudialyte group, minerals of the lovozerite group.

We compared the compositions of rock-forming minerals from lujavrite, foyaite, and urtite. Clinopyroxenes (aegirine and aegirine-augite) in lujavrite form small, long-prismatic crystals, and in urtite - large poikilitic grains. Yet, apart from morphology, they also differ in chemical composition. Clinopyroxenes from lujavrite are enriched in diopside component, while pyroxenes from urtite contain more aegirine end-member. Clinopyroxenes from foyaite are in an intermediate position. The evolution from diopside-rich pyroxene compositions towards aegirine-rich pyroxene is typical of alkaline massifs worldwide (Larsen, 1976). The major difference between various complexes is the amount of $\mathrm{Fe}^{2+}$ enrichment relative to $\mathrm{Na}$ and $\mathrm{Fe}^{3+}$ enrichment during their evolution (Korobeinikov, Laajoki, 1994).

The composition of eudialyte-group minerals also changes during the transition from lujavrite to foyaite and urtite. The ratio of manganese to ferrous iron in the eudialyte composition is maximum in urtite, while in lujavrite, it is lower. Such change indicates that lujavrite is the earliest rock of each rhythm, and urtite is the more evolved and latest one (Shilling et al., 2011). Amphiboles (arfvedsonite and magnesioarfvedsonite) in urtite and foyaite form large poikilitic crystals with inclusions of all surrounding minerals, and in lujavrite, amphiboles form anhedral grains located in the center of clinopyroxene segregations. In amphiboles from lujavrite, the aluminum and calcium contents are higher, and the silicon and sodium contents are lower than in amphiboles from leucocratic rocks. It is known that sodic amphiboles are stable only at low temperatures (below $650^{\circ} \mathrm{C}$ ) and pressures (Mitchell, 1990).

Thus, changes in the compositions of clinopyroxenes, amphiboles, and EGM indicate that each rhythm of the Layered complex consists of less- (lujavrite) and more-evolved (urtite) rocks. Fractionation of the melanocratic melt proceeded in the direction of enrichment with nepheline and a decrease in the aegirine content, i.e., from lujavrite to urtite. Such fractionation path occurs experimentally (Bailey, Schairer, 1966) in the $\mathrm{Na}_{2} \mathrm{O}-\mathrm{Al}_{2} \mathrm{O}_{3}-\mathrm{Fe}_{2} \mathrm{O}_{3}-\mathrm{SiO}_{2}$ system, where melt of the "ijolite" type (approximately $50 \%$ of aegirine) evolves towards "phonolitic eutectic" (approximately 10\% of aegirine). The results of our research are consistent with the conclusions of Féménias and colleagues (Féménias et al., 2005). We assume that the Lovozero massif was formed as a result of the injection of relatively small portions of alkaline melt into Devonian volcaniclastic rocks. Fractional crystallization took place in situ, in each such portion.

\section{Future prospects}

We plan to continue a detailed study on rock-forming minerals from different rocks of the Layered complex of the Lovozero massif. In particular, studies on the distribution of rare earth elements in minerals of the eudialyte group and loparite, crystal chemical studies of nepheline will be conducted. In addition, we are planning textural studies on magmatic rocks. 


\section{Acknowledgements}

The research was supported by the Ministry of Science and Higher Education of the Russian Federation (project 0226-2019-0051).

\section{References:}

Arzamastsev AA (1994) Unique Paleozoic Intrusions of the Kola Peninsula. Geological Institute of the Kola Science Centre, Apatity. 79 pp.

Bailey DK, Schairer JF (1966) The System $\mathrm{Na}_{2} \mathrm{O}-\mathrm{Al}_{2} \mathrm{O}_{3}-\mathrm{Fe}_{2} \mathrm{O}_{3}-\mathrm{SiO}_{2}$ at 1 atmosphere, and the petrogenesis of alkaline rocks. J Petrol 7:114-170.

Bussen IV, Sakharov AS (1972) Petrology of the Lovozero Alkaline Massif. Nauka, Leningrad, 296 pp.

Féménias O, Coussaert N, Brassinnes S, Demaiffe D (2005) Emplacement processes and cooling history of layered cyclic unit II-7 from the Lovozero alkaline massif (Kola Peninsula, Russia). Lithos 83:371-393. https://doi.org/10.1016/j.lithos.2005.03.012

Gerasimovsky VI, Volkov VP, Kogarko LN, Polyakov AI, Saprykina TV, Balashov YA (1966) Geochemistry of the Lovozero Alkaline Massif. Nauka, Moscow, 398 pp.

Kogarko LN, Williams CT, Woolley AR (2006) Compositional evolution and cryptic variation in pyroxenes of the peralkaline Lovozero intrusion, Kola Peninsula, Russia. Mineral mag 70:347-359. https://doi.org/10.1180/0026461067040340

Korobeinikov AN, Laajoki K (1994) Petrological aspects of the evolution of clinopyroxene composition in the intrusive rocks of the Lovozero alkaline massif. Geochemistry International 31:69-76.

Kramm U, Kogarko LN (1994) Nd and Sr isotope signatures of the Khibina and Lovozero agpaitic centres, Kola Alkaline province, Russia. Lithos 32:225-242. https://doi.org/10.1016/0024-4937(94)90041-8

Larsen LM (1976) Clinopyroxenes and Coexisting Mafic Minerals from the Alkaline Ilimaussaq Intrusion, South Greenland. Journal of Petrology 17:258-290. https://doi.org/10.1093/petrology/17.2.258

Mitchell RH (1990) A review of the compositional variation of amphiboles in alkaline plutonic complexes. Lithos 26:135-156. https://doi.org/10.1016/0024-4937(90)90044-2

Schilling J, Wu F-Y, McCammon C, et al (2011) The compositional variability of eudialyte-group minerals. Mineral mag 75:87-115. https://doi.org/10.1180/minmag.2011.075.1.87

Vlasov KA, Kuzmenko MZ, Eskova EM (1959) The Lovozero Alkaline Massif. Izdatel'stvo Akademii Nauk, Moscow, $450 \mathrm{pp}$. 